\title{
Australian manufacturing industry: a 20-year scoping study on barriers, opportunities and trends for its strategic development
}

\author{
Guilherme Tortorella ${ }^{\mathrm{a}, \mathrm{b} *}$ (D), Wen $\mathrm{Li}^{\mathrm{a}}$, Jo Staines ${ }^{\mathrm{a}}$, Roberto Vassolo ${ }^{\mathrm{c}}$ \\ aThe University of Melbourne, Melbourne, Australia \\ bUniversidade Federal de Santa Catarina, Florianópolis, SC, Brasil \\ 'Universidad Austral, Buenos Aires, Argentina \\ *gtortorella@bol.com.br
}

\begin{abstract}
Paper aims: This study aims at identifying the barriers, opportunities and trends for the strategic development of the Australian manufacturing industry.

Originality: As research on Australian manufacturing is prolific and sparse, our study helps to clarify whether and how important research findings on Australian manufacturing replicate.

Research method: For that, we conducted a scoping review on literature evidence published in the last twenty years. We systemically compiled the body of knowledge and proposed research directions in accordance with five global manufacturing megatrends.

Main findings: We identified eight barriers/challenges and eight opportunities according to manufacturing sectors and analyzed them based on their emphasis on these global megatrends. Literature emphasis has not been equally distributed over time, highlighting the need for further research.

Implications for theory and practice: We suggested three main directions for future studies; they were: $(i)$ digital transformation of manufacturing; (ii) sustainable operations in end-to-end service-integrated manufacturing; and (iii) interrelation between socioeconomic characteristics and strategic critical success factors. Further, the body of knowledge's systemic compilation has led to new conceptual and theoretical insights in light of global megatrends.
\end{abstract}

Keywords

Australia. Manufacturing industry. Strategic development. Scoping review.

How to cite this article: Tortorella, G., Li, W., Staines, J., \& Vassolo, R. (2021). Australian manufacturing industry: a 20-year scoping study on barriers, opportunities and trends for its strategic development. Production, 31, e20200120. https://doi.org/10.1590/0103-6513.20200120

Received: Dec. 20, 2020; Accepted: Feb. 23, 2021.

\section{Introduction}

Manufacturing is a relevant component of the Australian economy since it is the seventh-largest employer, the sixth-largest for output, and has the highest business expenditure on research and development (Al Group, 2019). The manufacturing industry also has strong links throughout the Australian economy through the flow of skills, knowledge and goods, using materials and services from other industries (e.g. mining and information and communications technologies) and providing manufactured products such as fertilizer to agriculture, or structural steel to construction (Australia, 2018). Having a diversity of activities, the leading manufacturing sectors in Australia are food and beverage, pharmaceuticals, chemical, and non-metallic minerals (Manufacturers' Monthly, 2019). 
Although the Australian manufacturing industry successfully overcame many challenges over the past years, its economic representativeness has reduced significantly (Yigitcanlar et al., 2019). For instance, in the 1960s, the contribution of manufacturing to Australian gross domestic product (GDP) was about 30\% (Australia, 2004). This value has continuously dropped since then, achieving 6\% approximately in 2018 (Al Group, 2019). Two main aspects may explain the reduction of this economic representativeness. The first one is the rapid increase in the contribution of the service sector, which employs almost $80 \%$ of the labor force and comprises more than $60 \%$ of Australian GDP (Australia, 2018). This trend on services has also been observed in other developed economies, such as USA, UK and Germany (United Nations Conference on Trade and Development, 2017). The second one is losing some key manufacturing companies in some industries, such as automotive and textile (Mazzarol, 2014; Centre for International Economics, 2017).

There is an alternative perspective among academics and practitioners that claims the Australian manufacturing industry is undergoing a significant change as novel digital technologies and new markets emerge (Foley \& McLean, 2016; Commonwealth Scientific and Industrial Research Organisation, 2016). Aspects such as high wages, geographical remoteness, small and dispersed domestic market, and shifts in consumers' preferences are also driving the transition of Australian manufacturing. Manufacturing is not a basic industry that employs low-skilled and low-paid workers anymore (Manufacturers' Monthly, 2019). According to the Al Group (2019) report, Australian manufacturing has faced some fundamental rebalancing concerning its sectors, products, technologies, and supply chains as a response to long-term local and global structural shifts. This change has been most prominent in food, beverages and groceries manufacturing, and in their respective supply chains.

Although recent studies report some trends and expectations on Australian manufacturing (e.g. Commonwealth Scientific and Industrial Research Organisation, 2016; Al Group, 2019), most academic works approach it from an isolated or narrow perspective lacking a systemic and holistic view of the current barriers and opportunities for its strategic development (Samson \& Gloet, 2018). Such a gap promotes misguided and biased directions that hinders the successful resumption of the Australian manufacturing industry (Lobo et al., 2012; Jayaram et al., 2014; Hu et al., 2019). Hence, the misalignment and randomness of research on Australian manufacturing prevent from precisely identifying implementation trends, opportunities, and challenges, leading to possible confusion and theoretical spraying of the research topic.

These theoretical and conceptual gaps become even more critical when considering the manufacturing megatrends and how they affect the Australian context. According to Singh (2012), Esposito \& Tse (2018) and Kalaitzi et al. (2020), megatrends global, sustained and macroeconomic forces of development that affect businesses, economies, societies, cultures and personal lives, thus influencing our future world and the encompassed changes. As time passes, global megatrends evolve according to different phenomena (Westkämper, 2014; Abele et al., 2019). The challenge relies on knowing how to read these megatrends so that companies can strategically anticipate their improvement efforts to gain competitive advantages worldwide (Hajkowicz, 2015; Biswas, 2018). Hence, identifying barriers, opportunities, and trends for Australian manufacturing's strategic development in the face of those megatrends is vital.

We acknowledge that, although this understanding is particularly relevant for the Australian manufacturing industry's strategic development, which is undergoing significant changes (Commonwealth Scientific and Industrial Research Organisation, 2016), it is also relevant to other national contexts. The Australian socioeconomic context resembles many other countries, such as Canada, New Zealand, UK and Switzerland (McMillan \& Western, 2000; Australian Bureau of Statistics, 2011; Organisation for Economic Cooperation and Development, 2020). Thus, the Australian manufacturing context can be used as a proxy for those countries, and findings may apply to a broader scenario providing the basis for a future theoretical and empirical generalization (Teng et al., 2014; Popa et al., 2018). Based on these arguments, we formulate two main research questions:

\section{RQ1. What are the main barriers/challenges, opportunities and trends for the strategic development of the Australian manufacturing industry?}

\section{RQ2. How do these barriers/challenges, opportunities and trends fit within the global manufacturing megatrends?}

This paper aims at identifying the barriers, opportunities and trends for the strategic development of the Australian manufacturing industry. For that, we conducted a scoping review, which is a method that systematically, explicitly and reproducibly identify, evaluate, and synthesize the existing studies produced by researchers, scholars, and practitioners (Fink, 2005). Scoping studies are particularly suitable when the research landscape vastly and sparsely differs in terms of concepts and approaches (Okoli \& Schabram, 2010; Siddaway et al., 2019). Besides, it provides a broader understanding of the extent, nature, and quality of evidence concerning the research topic, highlighting gaps between what is known and what is not (Arksey \& 0'Malley, 2005; Cooper, 2015). 
Scoping studies are a relatively new approach to evidence synthesis. Currently there is little guidance regarding the decision to choose between a systematic review or scoping review approach when synthesizing evidence (Munn et al., 2018). Nevertheless, the pervasiveness of scoping reviews on topics related to Operations and Supply Chain Management, Industrial Engineering and Manufacturing is extensive (e.g. Seo-Zindy \& Heeks, 2017; Hariharasudan \& Kot, 2018; Borges et al., 2019; Rosen \& Wischniewski, 2019; Tortorella et al., 2019), which illustrates the relevance of such a methodological approach to the field.

Because the literature on Australian manufacturing is prolific and multidisciplinary, we focused on evidence published in the last twenty years, as more recent studies are likely to lead to new insights and are often widely read (Ridley, 2012; Peters et al., 2018). Besides, our focus on the current megatrend makes it unnecessary to expand the analysis too far in time. Thus, our study helps to elucidate whether and how relevant research findings on Australian manufacturing depict, systemically compiling the body of knowledge and proposing research directions in accordance with global manufacturing megatrends.

\section{Global manufacturing megatrends}

The role played by the manufacturing industry has been changing over time, although it remains fundamental to both emerging and developed economies (Biswas, 2018). The manufacturing industry has passed through an enormous shift resultant from automation, innovation, high flexibility, agility and efficiency. Further, manufacturers need to be experienced in technology because of the quick technological changes and competitive pressures (Agarwal et al., 2018). Besides, market volatility, resources shortage and geographical distance have increased the complexity, uncertainty and interdependence of manufacturing value chains (Tortorella \& Fogliatto, 2008; Silveira et al., 2016). Therefore, manufacturers need to reformulate their value chains' processes and strategies in the face of global megatrends (Pagliaro, 2019; Abele et al., 2019).

Global megatrends entail a global structural change in almost all manufacturing sectors that influence technologies of products and processes, human labor, management, and resources. Different studies diverge in their observations about megatrends. López-Gómez et al. (2013) reported eight megatrends affecting the manufacturing sector at the global level. Later, López-Gómez et al. (2017) revised these indications and added another six megatrends, which are displayed in Table 1. It is worth noticing that global megatrends might slightly differ depending on certain aspects (e.g., manufacturing sector). For instance, Stank et al. (2015) discussed fifteen megatrends that are likely to affect supply chain management until 2025, taking both a practitioner and an academic perspective. Specifically, in terms of the Fourth Industrial Revolution, the World Economic Forum (2019) suggested that three technological megatrends are the critical drivers for manufacturing transformation: connectivity, intelligence, and flexible automation. Manufacturers that embraced these megatrends have observed a significant positive impact on performance (World Economic Forum, 2019).

The pervasiveness of global megatrends can also vary according to the socioeconomic context in which manufacturers locate. Particularly for the European manufacturing industry, Westkämper (2014) suggested eight megatrends that will influence its strategic development towards the 2030 vision: $(i)$ ageing of population; (ii) individualism and customization; (iii) knowledge in information and communication technology (ICT); (iv) globalization of manufacturing ecosystem; $(v)$ high level of urbanization; ( $v i$ ) sustainability of products, processes and services; (vi) turbulent finance markets; and (viii) public debt of State. Commonwealth Scientific and Industrial Research Organisation (2016) developed guidelines for a 20-year development horizon of the Australian manufacturing industry, in which it identifies five global megatrends:

(i) Made to measure: represents the change from mass production of goods to bespoke solutions caused by advances in technology and greater consumer expectations;

(ii) Supply chain transformations: denotes the greater collaboration and vertical integration levels promoted by specialization and technological advancements, respectively;

(iii) Sustainable operations: indicates the trend to search for more effective and sustainable processes and operating models due to resources shortage and highly valued environmental and social credentials;

(iv) Smart and connected: relate to the optimization of operations across the manufacturing value chain and the shop floor considering advances in data capture and analytics; and

(v) Service expansion: refers to the expansion of manufacturers' role in the value chain from producing 'widgets' to developing closely integrated service-product bundles. 
Table 1. Global manufacturing megatrends according different authors.

\begin{tabular}{|c|c|c|c|c|c|}
\hline $\begin{array}{c}\text { López-Gómez et al. } \\
\text { (2013) }\end{array}$ & Westkämper (2014) & Stank et al. (2015) & $\begin{array}{l}\text { Commonwealth } \\
\text { Scientific and } \\
\text { Industrial Research } \\
\text { Organisation (2016) }\end{array}$ & $\begin{array}{c}\text { López-Gómez et al. } \\
\text { (2017) }\end{array}$ & $\begin{array}{l}\text { World Economic } \\
\text { Forum (2019) }\end{array}$ \\
\hline -Demographics & -Ageing of population & -Glocal optimization & -Made to measure & $\begin{array}{l}\text {-Continuing ageing } \\
\text { of the workforce in } \\
\text { developed countries }\end{array}$ & -Connectivity \\
\hline $\begin{array}{l}\text {-Changing consumer } \\
\text { habits }\end{array}$ & $\begin{array}{l}\text {-Individualism and } \\
\text { customization }\end{array}$ & $\begin{array}{l}\text {-Intelligent value co- } \\
\text { creation }\end{array}$ & -Service expansion & $\begin{array}{l}\text {-Growing demand for } \\
\text { customized products }\end{array}$ & -Intelligence \\
\hline $\begin{array}{l}\text {-Accelerating } \\
\text { production life cycles }\end{array}$ & -Knowledge in 1CT & -Talent management & -Smart and connected & $\begin{array}{l}\text {-Changing } \\
\text { manufacturing skills' } \\
\text { needs }\end{array}$ & -Flexible automation \\
\hline -Globalization & $\begin{array}{l}\text {-Globalization of } \\
\text { manufacturing } \\
\text { ecosystem }\end{array}$ & $\begin{array}{l}\text {-Flexible network } \\
\text { integration }\end{array}$ & $\begin{array}{l}\text {-Supply chain } \\
\text { transformations }\end{array}$ & $\begin{array}{l}\text {-Growing interest } \\
\text { in industrial and } \\
\text { technological } \\
\text { strategies }\end{array}$ & \\
\hline -Urbanization & $\begin{array}{l}\text {-High level of } \\
\text { urbanization }\end{array}$ & -Transformation & $\begin{array}{l}\text {-Sustainable } \\
\text { operations }\end{array}$ & $\begin{array}{l}\text {-Increasing demand } \\
\text { for manufactured } \\
\text { goods in cities }\end{array}$ & \\
\hline -Sustainability & $\begin{array}{l}\text {-Sustainability of } \\
\text { products/processes/ } \\
\text { services }\end{array}$ & $\begin{array}{l}\text {-Relevant value } \\
\text { measurement }\end{array}$ & & $\begin{array}{l}\text {-Increased efforts to } \\
\text { support reshoring to } \\
\text { developed countries }\end{array}$ & \\
\hline $\begin{array}{l}\text {-Threats to global } \\
\text { stability }\end{array}$ & $\begin{array}{l}\text {-Turbulent finance } \\
\text { markets }\end{array}$ & $\begin{array}{l}\text {-Total value } \\
\text { orientation }\end{array}$ & & & \\
\hline \multirow{8}{*}{$\begin{array}{l}\text {-National industrial } \\
\text { policies }\end{array}$} & -Public debt of State & -Autonetic technology & & & \\
\hline & & -Systemic focus & & & \\
\hline & & -Prognostic agility & & & \\
\hline & & -Information synthesis & & & \\
\hline & & -Vested relationships & & & \\
\hline & & -Demand shaping & & & \\
\hline & & -Risk prognosis & & & \\
\hline & & -Prostainability & & & \\
\hline
\end{tabular}

Although these global manufacturing megatrends differ from each other, they commonly indicate movements on customization, connectivity and intelligence, and sustainability. Besides, since our study focuses on the Australian context, we further analyze the literature according to the five global manufacturing megatrends proposed by Commonwealth Scientific and Industrial Research Organisation (2016).

\section{Research design}

Scoping studies have become an increasingly popular method for synthesizing research evidence (Daudt et al., 2013; Munn et al., 2018), as they map the existing literature in a field of interest in terms of the volume, nature, and characteristics of the primary research (Arksey \& 0'Malley, 2005). This methodological approach can be useful when the topic has not yet been extensively reviewed or is of a complex or heterogeneous nature (Mays et al., 2001; Pham et al., 2014), which is the case of Australian manufacturing development. Scoping studies are generally performed to summarize and disseminate research findings, and identify research gaps in the existing literature (Arksey \& 0’Malley, 2005; Levac et al., 2010). As it provides a rigorous and transparent method for mapping the areas of research (Pham et al., 2014), we understand that a scoping review would be more suited to our research purpose and would help address the aforementioned research questions.

The research method has five main steps (Arksey \& 0'Malley, 2005): (i) identification of research questions; (ii) identification of important works; (iii) selection of works; (iv) charting of data; and ( $v$ ) collating, summarizing and reporting results. In step ( $)$, we identified essential aspects of the research topic to formulate the research questions that would guide the search strategies used here (Cooper, 2015). As indicated in the introductory section, we established two main research questions that motivated our study. To address those questions, we carried out a structured method that allowed us to raise robust evidence and findings, as detailed in the subsequent sections.

The step (ii) of the scoping review demands identifying important literature, regardless of the methodological approach (Peterson et al., 2017). We conducted our search throughout March 2020. As the review evolved, familiarity with the research topic increased, resulting in a two-stage search. This is a standard procedure followed 
by similar studies (e.g. Tortorella et al., 2019) that mitigates the issue of the search string being overly specific or entailing misleading buzzwords.

We initially determined two research dimensions associated with the research questions: Australia and Manufacturing. We combined a set of keywords ("Australia" AND "manufactur" AND "industr") to retrieve studies that utilized them in the title, abstract and/or keywords. The application of the AND operator in the search procedure minimized misleading outcomes. Following Borges et al.'s (2019) recommendations, we used three databases to search for scientific articles: Scopus, Compendex (Engineering Village), and Web of Science. Because this first stage sought to validate the initial set of keywords, we did not apply any filtering criteria to the search. In total, we retrieved 2,187 publications from the three databases, divided as follows: 905 from Scopus, 255 from Web of Science, and 1,207 from Compendex. In the second stage, we randomly picked five different articles from each database to compare their keywords with the ones from the research dimensions initially utilized (Borges et al., 2019). As the research on the studied topic is vast and scattered, taxonomies may differ and compromise the search. However, the comparison of these 15 manuscripts did not show any significant differences in the used keywords. Hence, we assumed the initial set was adequately defined, therefore we did not insert additional keywords.

In step (iii), two of the authors concurrently selected the studies. To include them, they both should agree to select them (Cooper, 2015). Several methodological procedures outline how to structure and report this step. We followed the guidelines from the Preferred Reporting Items for Systematic Reviews and Meta-Analyses (PRISMA), since it is widely useable across various research fields and fosters the establishment of a rationale and planned methods for the review (Siddaway et al., 2019). PRISMA comprises four stages: identification, screening, eligibility, and inclusion (Moher et al., 2009). From the 2,187 publications initially retrieved, we examined only articles in English published in peer-reviewed journals, which results in 1,179 articles. Although the utilization of grey literature is sometimes recommended depending on the research topic (Siddaway et al., 2019), we did not include it due to a lack of comparable search strings. Then, we removed duplicate publications, which reduced to 593 articles with their titles checked concerning alignment with the research dimensions. Next, we focused on evidence published in the last twenty years (i.e. after 2000), reducing the list to 277. Since we aimed at comparing the barriers, opportunities and trends in Australian manufacturing with current global megatrends, recent studies would provide more appropriate indications, while older studies could lead to outdated and, consequently, misleading findings. This justifies the utilization of articles published in the last twenty years.

These 277 works had their keywords and abstracts verified for alignment with the research topic (i.e., we checked whether these keywords/abstracts explicitly mentioned Australian manufacturing development), resulting in 125 articles and ending the screening stage. Next, these 125 articles went through the eligibility stage in which their full texts were analyzed for alignment with the research topic (i.e., we verified if these articles really focused Australian manufacturing industry), and 102 publications remained. We then assessed articles in terms of their relevance (e.g. generalizability, report and intervention quality, and authors' conflict of interest) and methodological rigor (e.g. study design's appropriateness and adequate sample size for achieving research objectives, respondents' selection methods, response rate, and measurement of variables) (Okoli \& Schabram, 2010). Whenever authors did not reach a consensus on a particular article, the third author was invited to review the article and a decision was made by majority vote. 18 publications were withdrawn based on these criteria. We examined the references of the remaining 84 articles to check for relevant works frequently cited but not yet added in our review. The quantitative analysis of references did not result in the inclusion of any study, and the literature portfolio used in the study comprised these 84 studies (Abbott, 2019; Alaouze, 2003; Athukorala et al., 2017; Baird et al., 2011; Barnes, 2017; Beaumont, 2005; Beer, 2018; Black et al., 2015; Boaden \& Sims, 2000; Boer et al., 2005; Bonn, 2000; Caldera et al., 2018; Cantù et al., 2015; Clibborn, 2012; Cooney; 2002; Correia et al., 2020; Craik, 2015; Cripps et al., 2009; Dargusch \& Ward, 2010; Feng et al., 2008; Fraser et al., 2013; Given, 2017; Gregory \& Sohal, 2002; Grodach \& Martin, 2020; Gu \& Yan, 2017; Hampson, 2012; Hasan et al., 2011; Hu et al., 2019; Jackson et al., 2018; Jayaram et al., 2014; Joiner et al., 2009; Jones, 2005; Kara \& Kayis, 2007; Karim et al., 2008; Kayis \& Kara, 2005; Kiridena et al., 2009; Le \& Valadkhani, 2014; Leahy et al., 2010; Liu \& McMurray, 2004; Lo \& Power, 2010; Lobo et al., 2009, 2012, 2018; Logue et al., 2015; Low et al., 2007; Marks, 2009; Mo, 2009; MoosaviRad et al., 2014; Nelson et al., 2007; O’Connor et al., 2015; Olive, 2008; Oliver \& Walpole, 2017; Penesis et al., 2017; Perera et al., 2019; Prajogo, 2006, 2007; Prajogo et al., 2012; Qureshi \& Evans, 2015; Reid, 2001; Schliephake et al., 2009; Sharma, 2003, 2004; Sheather, 2002; Singh \& Power, 2014; Smith, 2007; Smith et al., 2010, 2015; Sohal \& Terziovski, 2000; Sohal, 2001; Sohal \& Terziovski, 2000; Sohal et al., 2001, 2002; Soosay et al., 2016; Stewart, 2016; Teng et al., 2014; Teo et al., 2011; Truett \& Truett, 2017, 2018; Tung et al., 2011; Turnbull et al., 2016; Van der Eng, 2017; Watts et al., 2014; Weller \& 0’Neill, 2014; Wright et al., 2011). 
In step (iv), we charted and synthesized key data from the literature portfolio so that we could establish the grounds to interpret and consolidate findings (Levac et al., 2010). A descriptive-analytical method was conducted (Arksey \& 0'Malley, 2005), enabling a broader view of literature portfolio. Due to our study's objective, we organized publications in a spreadsheet based on authors, years of publication, journals, manufacturing sectors, barriers/challenges, opportunities, and trends. It is worth mentioning that barriers/challenges were considered exogenous obstacles to manufacturing organizations that prevent their strategic development; and opportunities were deemed endogenous circumstances that manufacturers could address to foster their strategic development.

In the final step ( $v$ ), we collated, summarized and reported results in accordance with five global manufacturing megatrends (Commonwealth Scientific and Industrial Research Organisation, 2016): (i) made to measure, (ii) supply chain transformations, (iii) sustainable operations, (iv) smart and connected, and ( $v$ ) service expansion. To enhance the consistency of the narrative report of the investigated literature, we performed two additional analyses (Levac et al., 2010). In the first one, we carried out a descriptive numerical summary and thematic analysis to collate and summarize results. The summary brought information on key characteristics of the literature (e.g. publication years, authors, journals, manufacturing sectors, etc.), partially supporting the answers to RQ1 and RQ2. The thematic analysis qualitatively examined articles' contents, raising conceptual and theoretical insights on the research topic, and complementing the answer to RQ1. Further, it helped to report and categorize the emphasis of both barriers/challenges and opportunities according to global megatrends, providing arguments to answer RQ2. The examination of such emphases was performed based on the frequency analysis of articles from the literature portfolio that approached those barriers/challenges in light of each megatrend. In the second one, we discussed in a broader context practical and theoretical contributions of our findings, increasing the scoping review's legitimacy (Arksey \& 0’Malley, 2005). Such discussion also allowed us to identify research gaps and propositions of directions for further works.

\section{Results}

Figure 1 shows the descriptive numerical summary of the literature portfolio. Research on the Australian manufacturing industry has slightly increased over the past twenty years, evidenced by the positive slope of the trend of the number of publications per year. It is worth mentioning that the number of publications in 2020 might be affected by the period of sifting of the databases (i.e. March 2020), which suggests that more articles would be found had this search was performed later in the year. Further, the literature portfolio presented a total of 159 authors, from which 22 contributed with two or more articles and the remaining 137 participated in only one publication. The scattered distribution of researchers typically characterizes the incipience of a research topic. A similar distribution was found with respect to journals in which most studies have been published. 54 journals presented only one article, while 11 journals published two or more studies on the topic. The aim and scope of these 11 journals vary between two main streams. The first stream of journals publishes studies on innovation management, design of products, optimization of manufacturing processes and logistics systems, formulation of strategies and policies on manufacturing, and new technologies integration (e.g. International Journal of Operations and Production Management and International Journal of Production Research). The

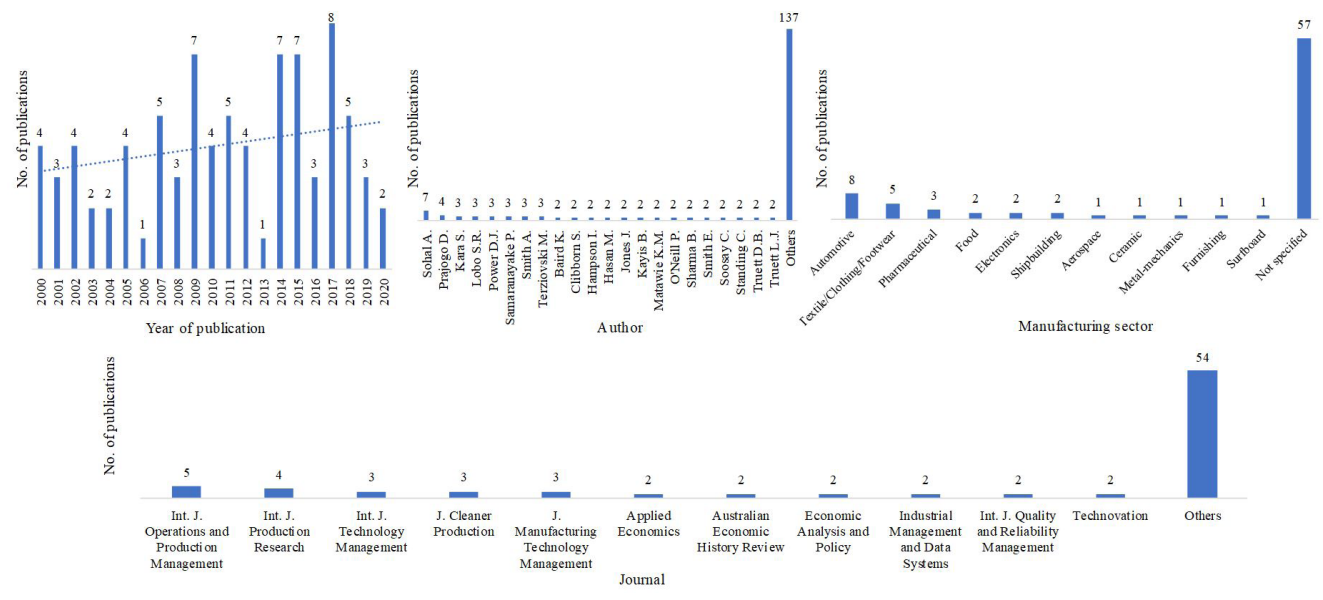

Figure 1. Quantitative analysis of the literature portfolio. Note: Publications from 2020 are not entirely considered since the search in the databases was conducted in March 2020. 
second one mainly focuses on the application of economic, social and business analyses to specific problems in both public and private sectors (e.g. Applied Economics and Economic Analysis and Policy). In general, the dichotomization of publications between both streams points that this topic has been approached either from an operations and supply chain management perspective or from a social and economic standpoint, lacking an integrated and systemic approach related to the key aspects of the Australian manufacturing industry. With respect to manufacturing sectors, most studies did not address any particular sector and approached the manufacturing industry in a general sense. Among the studies that focused on a specific sector, the automotive industry has surprisingly stood out. Although the last automobiles manufactured in Australia rolled off the assembly line in the end of 2017, publications on this manufacturing sector continued to occur (e.g. Beer, 2018; Truett \& Truett, 2018) and to raise attention from academicians. In total, eleven manufacturing sectors were explicitly discussed in the literature portfolio, reasonably representing the Australian manufacturing industry spectrum.

Tables 2 and 3 consolidate the thematic analysis of barriers/challenges and opportunities, respectively, for the strategic development of the Australian manufacturing industry. We divided the literature based on the emphasis on each manufacturing sector and indicated the citation frequency accordingly. Based on the literature portfolio, eight barriers/challenges were prominently cited from which the small size of the Australian market $\left(b_{7}\right)$ seemed to be the most cited one (29 citations), negatively affecting the development of industries such as automotive, textile, clothing and footwear, metal-mechanics and electronics. According to Truett \& Truett $(2017,2018)$, the small size of the Australian market limits the capital expenditure efforts to increase manufacturers' capacity. To a certain extent, this fact also diminishes the attractiveness of Australia as a manufacturing hub, especially in the production of low value-added goods (Stewart, 2016; Turnbull et al., 2016). The second barrier that stood out the most was the manufacturing industry dominated by subsidiaries of multinationals $\left(b_{1}\right)$, which refers to the fact that very few manufacturers have ownership in Australia. This barrier implies that most of the knowledge remains abroad, not contributing to the local development of specialized technical teams (Baird et al., 2011; Van der Eng, 2017; Pancholi et al., 2019). Further, as the headquarter of these multinationals are mostly outside Australia, decisions about the future of these manufacturers are unlikely to consider socioeconomic implications to local communities and businesses (Le \& Valadkhani, 2014; Craik, 2015).

With regards to opportunities for the strategic development of Australian manufacturing, the adoption of continuous improvement practices $\left(o_{3}\right)$ was the most cited one (28 citations), with particular relevance to food, textile, clothing and footwear, metal-mechanics, furnishing and automotive (even though this last one has no longer manufacturers located in Australia). Literature reported some consistent initiatives related to the adoption of practices from improvement approaches such as total quality management (Fraser et al., 2013), lean manufacturing (Mo, 2009), supply chain management (Schliephake et al., 2009), among others. Despite this evidence, researchers (e.g. Prajogo et al., 2012; Lobo et al., 2018) claim that, in general, Australian manufacturers still present a low maturity level and need to reinforce the adoption of these practices so that they fully benefit from them. The second opportunity with the highest number of citations was to foster the development of local partnerships $\left(o_{4}\right)$. This opportunity has a close connection with both aforementioned barriers. The development of local suppliers and partners that can satisfactorily meet requirements on quality, cost, delivery, etc., contributes to a stronger domestic value chain (Perera et al., 2019; Abbott, 2019), mitigating the effects from the size of the Australian market and the dominance of multinationals.

Finally, we analyzed the emphasis of these barriers/challenges and opportunities for the strategic development of Australian manufacturing according to the five global manufacturing megatrends. Figure 2 displays the trends on literature emphasis throughout the last twenty years. For barriers/challenges, researchers have focused on them from the perspective of the megatrend supply chain transformations; i.e. barriers/challenges were most frequently discussed from the supply chain transformations standpoint. The concurrent trends on vertical integration, enabled by advanced ICT, and supply chain collaboration, promoted by greater market specialization, have led manufacturers to focus on specific niches in which the same firm can design, prototype and produce a product in a close relationship with the end consumer (Commonwealth Scientific and Industrial Research Organisation, 2016). In this sense, it is reasonable to expect that some barriers/challenges such as $b_{1}$ and $b_{7}$ were extensively discussed, emphasizing the difficulties that they may generate to this supply chain transformation. Further, existing import/export taxation $\left(b_{6}\right)$ also plays a key role in this transformation, since it might impair the collaboration with suppliers/customers that are not located in Australia (Weller \& O'Neill, 2014; Logue et al., 2015).

It is worth mentioning that the emphasis of barriers/challenges according to global megatrends does not appear to have an equal distribution throughout time. While made to measure, supply chain transformations and service expansion seem to be consistently emphasized over the last twenty years; smart and connected and sustainable operations are more recently referred to. The associations between barriers/challenges for the strategic development of Australian manufacturing and megatrends smart and connected and sustainable 


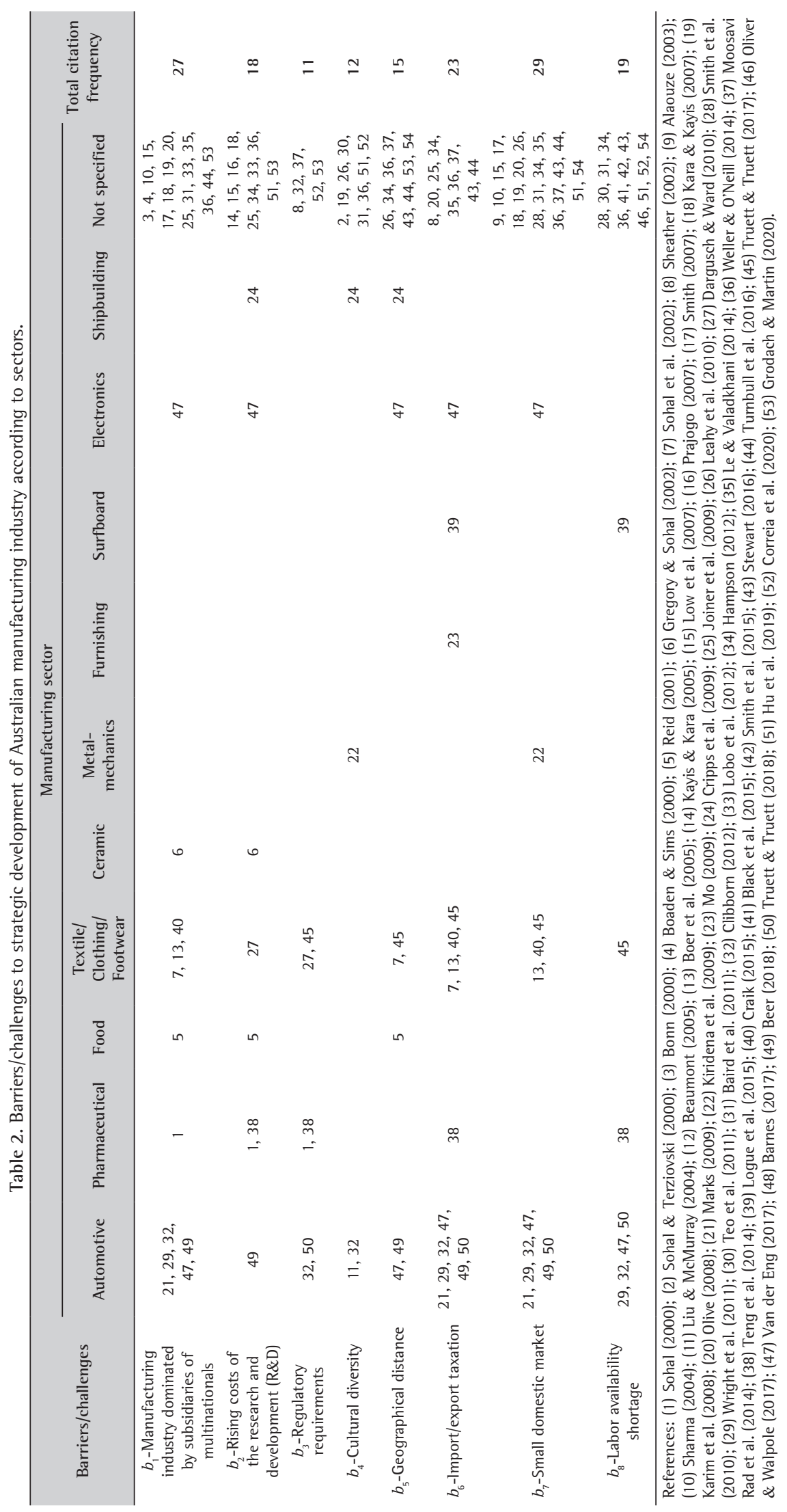




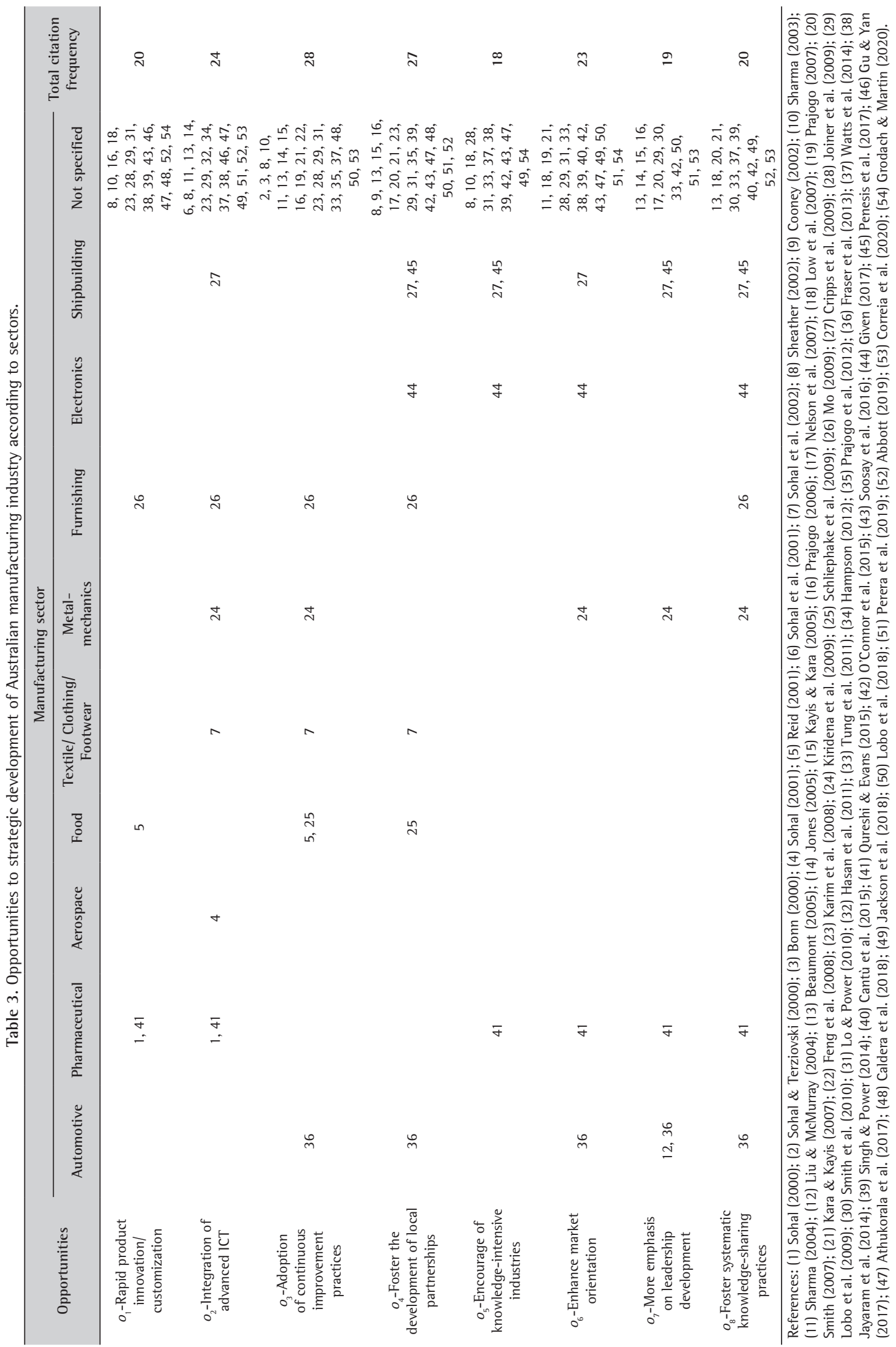


operations were first evidenced in 2005 and 2007, respectively. However, they seem to have evolved differently over the past few years. Although the first one has had a steady and modest emphasis in the literature, the second seems to be gaining more importance in the discussion of barriers/challenges. For instance, sustainable operations accounted for half of the literature emphasis in 2019, evidencing the increasingly research attention (e.g. Hu et al., 2019). Thus, due to the relatively little evidence and modest emphasis over the past years, one might assume that there is still much to understand the barriers/challenges related to smart and connected.

In terms of Australian manufacturing opportunities, trends in literature emphasis are slightly less contrasting. Overall, supply chain transformations was the most emphasized global megatrend with respect to opportunities, followed by made to measure and service expansion. Interestingly, opportunities from the perspective of smart and connected seem to be discussed since early 2000s (e.g. Sohal, 2000). However, with the beginning of the Fourth Industrial Revolution (World Economic Forum, 2019) one would expect that the emphasis on this megatrend could significantly increase over the past years, which was not observed in our literature portfolio. In fact, the association between opportunities and this megatrend was relatively steady in these twenty years, surprisingly suggesting that researchers did not pay much attention to this megatrend within the Australian manufacturing context. In opposition, opportunities, such as $o_{7}$-more emphasis on leadership development (Qureshi \& Evans, 2015; 0'Connor et al., 2015) and $o_{8}$-foster systematic knowledge-sharing practices (Jackson et al., 2018; Correia et al., 2020), have been increasingly discussed from the perspective of sustainable operations. Analogously to barriers/challenges, the discussion of opportunities from sustainable operations standpoint was more recently observed but lately received much emphasis within the Australian manufacturing context.

Overall, Table 4 summarizes the main barriers and opportunities in Australian manufacturing industry and categorizes them according to each global megatrend.

Table 4. Main opportunities and barriers categorized according to global megatrends.

\begin{tabular}{|c|c|c|c|c|c|}
\hline $\begin{array}{c}\text { López-Gómez et al. } \\
\text { (2013) }\end{array}$ & Westkämper (2014) & Stank et al. (2015) & $\begin{array}{l}\text { Commonwealth } \\
\text { Scientific and } \\
\text { lndustrial Research } \\
\text { Organisation (2016) }\end{array}$ & $\begin{array}{c}\text { López-Gómez et al. } \\
\text { (2017) }\end{array}$ & $\begin{array}{l}\text { World Economic } \\
\text { Forum (2019) }\end{array}$ \\
\hline -Demographics & -Ageing of population & -Glocal optimization & -Made to measure & $\begin{array}{l}\text {-Continuing ageing } \\
\text { of the workforce in } \\
\text { developed countries }\end{array}$ & -Connectivity \\
\hline $\begin{array}{l}\text {-Changing consumer } \\
\text { habits }\end{array}$ & $\begin{array}{l}\text {-Individualism and } \\
\text { customization }\end{array}$ & $\begin{array}{l}\text {-Intelligent value } \\
\text { co-creation }\end{array}$ & -Service expansion & $\begin{array}{l}\text {-Growing demand for } \\
\text { customized products }\end{array}$ & -Intelligence \\
\hline $\begin{array}{l}\text {-Accelerating } \\
\text { production life cycles }\end{array}$ & -Knowledge in 1CT & -Talent management & -Smart and connected & $\begin{array}{l}\text {-Changing } \\
\text { manufacturing skills' } \\
\text { needs }\end{array}$ & -Flexible automation \\
\hline -Globalization & $\begin{array}{l}\text {-Globalization of } \\
\text { manufacturing } \\
\text { ecosystem }\end{array}$ & $\begin{array}{l}\text {-Flexible network } \\
\text { integration }\end{array}$ & $\begin{array}{l}\text {-Supply chain } \\
\text { transformations }\end{array}$ & $\begin{array}{l}\text {-Growing interest } \\
\text { in industrial and } \\
\text { technological } \\
\text { strategies }\end{array}$ & \\
\hline -Urbanization & $\begin{array}{l}\text {-High level of } \\
\text { urbanization }\end{array}$ & -Transformation & $\begin{array}{l}\text {-Sustainable } \\
\text { operations }\end{array}$ & $\begin{array}{l}\text {-Increasing demand } \\
\text { for manufactured } \\
\text { goods in cities }\end{array}$ & \\
\hline -Sustainability & $\begin{array}{l}\text {-Sustainability of } \\
\text { products/processes/ } \\
\text { services }\end{array}$ & $\begin{array}{l}\text {-Relevant value } \\
\text { measurement }\end{array}$ & & $\begin{array}{l}\text {-lncreased efforts to } \\
\text { support reshoring to } \\
\text { developed countries }\end{array}$ & \\
\hline $\begin{array}{l}\text {-Threats to global } \\
\text { stability }\end{array}$ & $\begin{array}{l}\text {-Turbulent finance } \\
\text { markets }\end{array}$ & $\begin{array}{l}\text {-Total value } \\
\text { orientation }\end{array}$ & & & \\
\hline \multirow{8}{*}{$\begin{array}{l}\text {-National industrial } \\
\text { policies }\end{array}$} & -Public debt of State & -Autonetic technology & & & \\
\hline & & -Systemic focus & & & \\
\hline & & -Prognostic agility & & & \\
\hline & & -Information synthesis & & & \\
\hline & & -Vested relationships & & & \\
\hline & & -Demand shaping & & & \\
\hline & & -Risk prognosis & & & \\
\hline & & -Prostainability & & & \\
\hline
\end{tabular}




\section{Research directions}

Based on the descriptive numerical summary and thematic analysis of the literature portfolio, we identified three main research directions for better understanding the strategic development of Australian manufacturing industry. These directions are subsequently presented and discussed.

\subsection{Digital transformation of manufacturing}

As manufacturers worldwide start to join the Fourth Industrial Revolution (also referred to as Industry 4.0) by integrating disruptive ICT into products, processes and services, business models and performance standards are supposed to be significantly affected (World Economic Forum, 2019). Much evidence has been generated on Industry 4.0 and the benefits envisioned from its adoption to various manufacturing sectors (Lopes \& Barbosa, 2014; Pagliosa et al., 2019) and socioeconomic contexts (Rossini et al., 2019). However, when considering the Australian manufacturing context, which is similar to the Canadian, New Zealander, Swiss and Spanish, literature is still scarce and little emphasis has been placed on the subject. This could be observed by the trends on barriers/challenges and opportunities in relation to the megatrend smart and connected (see Figure 2).

The convergence of technologies such as wireless sensors, collaborative robots, additive manufacturing, embedded systems and interconnectivity is allowing the integration of real-time information throughout manufacturing and supply chain operations (Commonwealth Scientific and Industrial Research Organisation, 2016). This digital transformation is leading to interconnected smart factories that constantly measure and calibrate themselves to maximize efficiency. Additionally, the digitization of manufacturing has further implications on employees and the cognitive systems used to adapt and learn from past experiences. However, most studies have been conducted in high value-added manufacturing contexts (e.g. automotive and aerospace), and it is not entirely clear how manufacturers of low value-added goods (e.g. furnishing and ceramics) can also benefit from digital transformation.

As the Australian manufacturing industry is reasonably composed of both high and low value-added manufacturers, future studies could verify the differences that such contexts would entail in their digital transformation. Moreover, research could be performed to check how the digitization of Australian manufacturing would encourage the establishment of knowledge-intensive industries, which is highly associated with the technological advances from Industry 4.0 and a key opportunity identified in our scoping study. This particular opportunity would also be valid for manufacturing contexts such as the Swiss and South Korean. It is also worth noticing that researchers could address the sociocultural changes generated by Australian manufacturing digitization, comparing them with other socioeconomic contexts (e.g. Nascimento et al., 2019) and raising original findings to manufacturers of different technological intensities and tier levels.
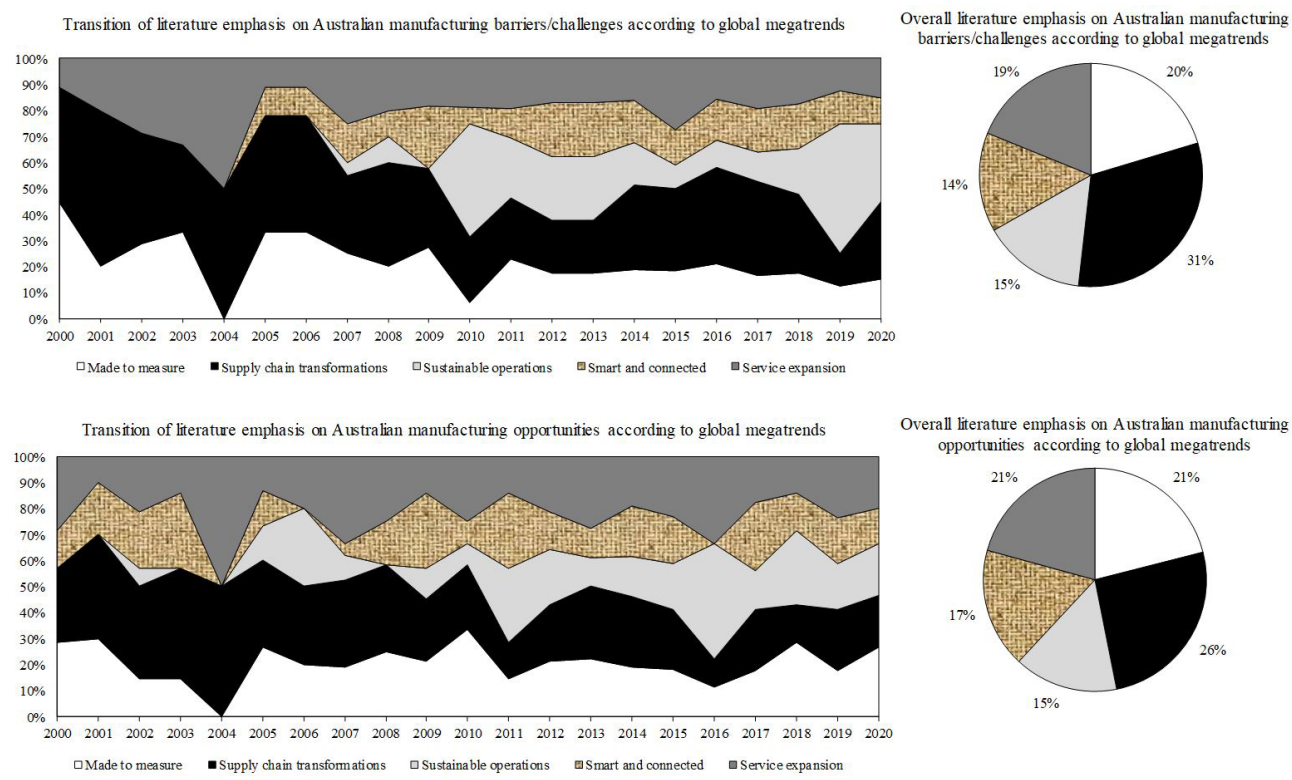

Figure 2. Literature emphasis on Australian manufacturing barriers/challenges and opportunities according to global megatrends 


\subsection{Sustainable operations in end-to-end service-integrated manufacturing}

With the population growth, there is a significant increase in the demand for manufactured goods, leading to rapid industrialization. To support such an increase, resources (e.g. energy, water, minerals) will have a greater need, despite the limited supply in the natural world (Silva et al., 2016; Caldera et al., 2018). This fact arouses concern with specific practices and management approaches that allow manufacturers to become socially, environmentally and financially sustainable (Soosay et al., 2016; Jones \& Zubielqui, 2017). Over the last decade, researchers have put an increasingly attention on this perspective, as observed in Figure 2. However, those studies have focused on manufacturers as a single echelon of the supply chain, neglecting other concurrent trends such as vertical integration and servitization of the Australian manufacturing industry (Commonwealth Scientific and Industrial Research Organisation, 2016).

As the scope of manufacturers becomes broader, their assignments begin with research and development, pass through manufacturing and assembly, and end with advertising, marketing and after-market services (Al Group, 2019), characterizing an end-to-end manufacturing. Additionally, as highlighted by Given (2017) and Athukorala et al. (2017), manufacturers need to move from a product-centered organizational model to a customer-oriented business, in which competitiveness will be sought based on a subtle balance between lower cost products and higher quality services enhancing market orientation. Thus, the combination between vertical integration and servitization results in a greater challenge for the development of sustainable operations, whose focus needs to be expanded way beyond the usual factory boundaries.

Future studies could approach such issue, merging concepts of sustainability and circular economy (Li et al., 2016; Hu et al., 2019) with servitization (United Nations Conference on Trade and Development, 2017) and supply chain management (Dargusch \& Ward, 2010; Lo \& Power, 2010) within Australian manufacturing context. Similarly, in countries where urbanization plays a vital role (e.g. Canada, New Zealand, and Switzerland), manufacturing operations lose areas and are prone to mix with large cities. In this scenario, the relevance of sustainable operations in end-to-end service-integrated manufacturing substantially increases. Furthermore, as the number of consumers who do not wish the financial and environmental burden related to product ownership increases (Commonwealth Scientific and Industrial Research Organisation, 2016), Australian manufacturers must reconceptualize their products and services into a collaborative consumption adapting themselves to a sustainable sharing economy (Matzler et al., 2015). Therefore, there are many opportunities for researchers to explore this direction through complementary approaches such as empirical and analytical studies.

\subsection{Interrelation between socioeconomic characteristics and strategic critical success factors}

A key issue for the strategic development of organizations relies on their capability of maintaining resources, processes and services up to date with changing contextual dynamics, also denoted as dynamic capabilities (Helfat $\&$ Winter, 2011). Dynamic capabilities concern a company's capacity to perceive new opportunities in its context and use them to motivate adaptation, integration, and reconfiguration of such resources, processes and services ensuring its long-term success (Salvato \& Vassolo, 2018). Due to our study's purpose, contextual dynamics may be understood as economic and social characteristics and trends of Australia, while an organization's resources, processes and activities might be labelled as critical success factors of manufacturers.

Dynamic capabilities might be seen from multilevel perspectives: organizational and individual level. The former entails higher-level view of organizational routines or decision-making rules (Schilke, 2014). The latter interprets dynamic capabilities as activities that support decision-making processes grounded on the skills of one or a few senior managers (Helfat \& Peteraf, 2015). Understanding this multilevel nature of organizational adaptation processes is at the root of successful change (Salvato \& Vassolo, 2018). An analogous interpretation can be made from the analysis of our scoping review. As evidenced in the literature portfolio, research on Australian manufacturing has been conducted from one of the two perspectives; either researchers approach the subject from an economic level exclusively relating their findings with economic aspects, or they narrow their studies on endogenous strategic factors that may be critical for companies' success.

The existence of such dichotomous approaches focusing just on one level of analysis entails both theoretical and practical gaps, undermining the establishment of a systemic and holistic understanding of the critical success factors for manufacturers' strategic development. In this sense, we suggest that future research could address this view by examining the interrelation between socioeconomic characteristics of Australia and the strategic critical success factors, determining the levels and orientation of this association across different manufacturing sectors. This research opportunity is also applicable to similar economies, such as New Zealand and the UK. Moreover, this multilevel analysis might be expanded to the understanding of the relationship of 
particular organizational routines and broader environmental changes. While addressing multilevel analysis generates non-trivial empirical challenges, they also offer unique opportunities for understanding how the manufacturing sector in socioeconomic contexts that resemble the Australian can overcome barriers and take advantage of global opportunities.

\section{Conclusions}

This paper aims to identify the barriers/challenges, opportunities and trends for the strategic development of the Australian manufacturing industry according to five global megatrends. A 20-year scoping study was conducted so that the body of knowledge could be systemically compiled, and a research agenda proposed. Eight barriers/challenges and eight opportunities were consolidated according to manufacturing sectors and analyzed based on their emphasis on five global megatrends.

In terms of theoretical implications, our study evidenced that the emphasis of previous research has not been equally distributed over time, highlighting the need for further studies. More specifically, we suggested three main directions for future studies; they were: ( $i$ ) digital transformation of manufacturing; (ii) sustainable operations in end-to-end service-integrated manufacturing; and (iii) interrelation between socioeconomic characteristics and strategic critical success factors. The body of knowledge on the Australian manufacturing industry has been randomly developed and often disconnected from the upcoming global megatrends. Our research has compiled this body of knowledge so that the trends, opportunities, and barriers for Australian manufacturing's strategic development could be compared with the global megatrends. To the best of our knowledge, there is no previous study that provides similar theoretical outcomes.

Regarding practical contributions, identifying opportunities, barriers, and trends of Australian manufacturing allows organizations to verify potential issues that undermine their competitiveness in the current global scenario, prioritizing managerial efforts that can anticipate and curb those issues. Moreover, the investigation on the proposed research directions can provide manufacturers timely arguments to support their growth in face of the socioeconomic and political changes implied by the global megatrends. Therefore, our study enlightens new paths for Australia's manufacturing industry and other countries with similar characteristics (e.g., Canada, New Zealand, and Switzerland) to compete worldwide.

Some limitations of this research are worth mentioning. The first one is related to the search procedure. Because databases were accessed in March 2020, articles published after this month were not considered. This drawback influenced both quantitative and qualitative analysis of this year. Further, we accounted for only three databases. Although they are widely deemed from the academic perspective, additional databases and grey literature could present relevant articles that were not included in our literature portfolio. A second limitation concerns the global megatrends utilized to frame our thematic analysis. As evidenced in Table 1, there is no clear consensus on the actual global manufacturing megatrends, and those are constantly being reassessed. Our findings are somewhat restricted by the global megatrends identified by Commonwealth Scientific and Industrial Research Organisation (2016). Therefore, the utilization of additional megatrends might raise complementary insights that were not identified in our study. Finally, Australian researchers and institutes have contributed to a growing body of manufacturing knowledge that is rather global-oriented than a localized solution. A further extension of work within this particular context would draw a more complete picture of research activities in Australia and other similar manufacturing scenarios, such as Canadian and New Zealander.

\section{References}

Abbott, M. (2019). The United Kingdom's economic relations with New Zealand and Australia after Brexit. The Round Table, 108(1), 21-35. http://dx.doi.org/10.1080/00358533.2019.1565341.

Abele, E., Metternich, J., \& Tisch, M. (2019). Challenges for future production/manufacturing. In E. Abele, J. Metternich \& M. Tisch (Eds.), Learning factories (pp. 1-21). Cham: Springer. http://dx.doi.org/10.1007/978-3-319-92261-4_1.

Agarwal, R., Chowdhury, M., \& Paul, S. (2018). The future of manufacturing global value chains, smart specialization and flexibility! Global Journal of Flexible Systems Management, 19(Suppl. 1), S1-S2. http://dx.doi.org/10.1007/s40171-018-0186-8.

Al Group. (2019). Australian manufacturing in 2019: local and global opportunities. Sydney: The Australian Industry Group.

Alaouze, C. (2003). A modified logit model for time series with an application to the pricing behaviour of manufacturing firms in Australia. Empirical Economics, 28(3), 599-613. http://dx.doi.org/10.1007/s001810200148.

Arksey, H., \& 0'Malley, L. (2005). Scoping studies: towards a methodological framework. International Journal of Social Research Methodology, 8(1), 19-32. http://dx.doi.org/10.1080/1364557032000119616.

Athukorala, P., Talgaswatta, T., \& Majeed, O. (2017). Global production sharing: exploring Australia's competitive edge. World Economy, 4O(10), 2172-2192. http://dx.doi.org/10.1111/twec.12495. 
Australia. Department of Industry, Innovation and Science. (2018). Industry insights. Canberra: Office of the Chief Economist, Australian Government. Retrieved in 2020, July 17, from https://www.industry.gov.au/data-and-publications/industry-insights

Australia. Productivity Commission. (2004). Trends in Australian manufacturing (No. 0402003). Melbourne.

Australian Bureau of Statistics. (2011). Measures of socioeconomic status. Canberra: Commonwealth of Australia. Retrieved in 2020, July 14, from https://www.ausstats.abs.gov.au/Ausstats/subscriber.nsf/0/367D3800605DB064CA2578B60013445C/\$File/1244055001_2011.pdf

Baird, K., Hu, K., \& Reeve, R. (2011). The relationships between organizational culture, total quality management practices and operational performance. International Journal of Operations \& Production Management, 31(7), 789-814. http://dx.doi. org/10.1108/01443571111144850.

Barnes, T. (2017). Industry policy in Asia’s demographic giants: China, India and Indonesia compared. Economic and Labour Relations Review, 28(2), 218-233. http://dx.doi.org/10.1177/1035304616656562.

Beaumont, N. (2005). Best practice in Australian manufacturing sites. Technovation, 25(11), 1291-1297. http://dx.doi.org/10.1016/j. technovation.2004.09.004.

Beer, A. (2018). The closure of the Australian car manufacturing industry: Redundancy, policy and community impacts. The Australian Geographer, 49(3), 419-438. http://dx.doi.org/10.1080/00049182.2017.1402452.

Biswas, R. (2018). Emerging manufacturing hubs. In R. Biswas (Ed.), Emerging markets megatrends. Cham: Palgrave Macmillan. http:// dx.doi.org/10.1007/978-3-319-78123-5_7.

Black, S., Yasukawa, K., \& Brown, T. (2015). The literacy and numeracy 'crisis' in Australian workplaces: discursive rhetoric vs. production floor realities. Journal of Education and Work, 28(6), 607-630.

Boaden, R., \& Sims, J. (2000). Manufacturing assessment using Schonberger's 16 customer-focused principles. Sprouts: Working Papers on Information Systems, 2(1-7), 580-619. http://dx.doi.org/10.1504/1JMTM.2000.001366.

Boer, H., Drejer, A., \& Buxey, G. (2005). Globalisation and manufacturing strategy in the TCF industry. International Journal of Operations \& Production Management, 25(2), 100-113. http://dx.doi.org/10.1108/01443570510576985.

Bonn, 1. (2000). Staying on top: characteristics of long-term survival. Journal of Organizational Change Management, 13(1), $32-48$. http://dx.doi.org/10.1108/09534810010371341.

Borges, G., Tortorella, G., Rossini, M., \& Portioli-Staudacher, A. (2019). Lean implementation in healthcare supply chain: a scoping review. Journal of Health Organization and Management, 33(3), 304-322. http://dx.doi.org/10.1108/JHOM-06-2018-0176. PMid:31122116.

Caldera, H., Desha, C., \& Dawes, L. (2018). Exploring the characteristics of sustainable business practice in small and medium-sized enterprises: experiences from the Australian manufacturing industry. Journal of Cleaner Production, 177, 338-349. http://dx.doi. org/10.1016/j.jclepro.2017.12.265.

Cantù, C., Corsaro, D., Tunisini, A., Zubielqui, G., Jones, J., Seet, P., \& Lindsay, N. (2015). Knowledge transfer between actors in the innovation system: a study of higher education institutions (HEIS) and SMES. Journal of Business and lndustrial Marketing, 30(3/4), 436-458. http://dx.doi.org/10.1108/JBIM-07-2013-0152.

Centre for International Economics - CIE. (2017). Australian trade liberalization: analysis of the economic impacts. Canberra: Australian Department of Foreign Affairs and Trade.

Clibborn, S. (2012). Local responses to a global downturn: labour adjustment in two multinational companies. The Journal of Industrial Relations, 54(1), 41-56. http://dx.doi.org/10.1177/0022185611432386.

Commonwealth Scientific and Industrial Research Organisation - CSIRO. (2016). Advanced manufacturing: a roadmap for unlocking future growth opportunities for Australia. Canberra: CSIRO Futures.

Cooney, R. (2002). The contingencies of partnership: Experiences from the training reform agenda in Australian manufacturing. Employee Relations, 24(3), 321-334. http://dx.doi.org/10.1108/01425450210428471.

Cooper, H. (2015). Research synthesis and meta-analysis: a step-by-step approach (Vol. 2). Thousand Oaks: Sage.

Correia, J., Sutrisna, M., \& Zaman, A. (2020). Factors influencing the implementation of off-site manufacturing in commercial projects in Western Australia. Journal of Engineering. Design and Technology, 18(6), 1449-1468. http://dx.doi.org/10.1108/JEDT-09-2019-0246.

Craik, J. (2015). Challenges for Australian fashion. Journal of Fashion Marketing and Management, 19(1), 56-68. http://dx.doi. org/10.1108/JFMM-03-2014-0017.

Cripps, H., Salo, J., \& Standing, C. (2009). Enablers and impediments to IT adoption in business relationships. Journal of Systems and Information Technology, 11(2), 185-200. http://dx.doi.org/10.1108/13287260910955138.

Dargusch, P., \& Ward, A. (2010). Understanding corporate social responsibility with the integration of supply chain management in outdoor apparel manufacturers in North America and Australia. International Journal of Business and Management Science, 3(1), 93-105.

Daudt, H., Van Mossel, C., \& Scott, S. (2013). Enhancing the scoping study methodology: a large, inter-professional team's experience with Arksey and O'Malley's framework. BMC Medical Research Methodology, 13(1), 48. http://dx.doi.org/10.1186/1471-2288-1348. PMid:23522333.

Esposito, M., \& Tse, T. (2018). DRIVE: the five megatrends that underpin the future business, social, and economic landscapes. Thunderbird International Business Review, 60(1), 121-129. http://dx.doi.org/10.1002/tie.21889.

Feng, M., Terziovski, M., \& Samson, D. (2008). Relationship of ISO 9001: 2000 quality system certification with operational and business performance. Journal of Manufacturing Technology Management, 19(1), 22-37. http://dx.doi.org/10.1108/17410380810843435.

Fink, A. (2005). Conducting research literature reviews: from the internet to paper (2nd ed.). Thousand Oaks: Sage Publications.

Foley, C., \& Mclean, K. (2016, November 27). The Australian manufacturing industry is not dying, it's evolving: CSIRO study. The Conversation. Retrieved in 2020, July 17, from https://theconversation.com/the-australian-manufacturing-industry-is-not-dyingits-evolving-csiro-study-69398

Fraser, K., Tseng, B., \& Hvolby, H. (2013). TQM in new car dealerships: a study from the firms' perspective. The TQM Journal, 25(1), 5-17. http://dx.doi.org/10.1108/17542731311286397.

Given, J. (2017). Born global, made local: multinational enterprise and Australia's early wireless industry. Australian Economic History Review, 57(2), 158-193. http://dx.doi.org/10.1111/aehr.12031. 
Gregory, C., \& Sohal, A. (2002). Global product development in the ceramic tiles industry. International Journal of Technology Management, 24(1), 17-26. http://dx.doi.org/10.1504/1JTM.2002.003041.

Grodach, C., \& Martin, D. (2020). Zoning in on urban manufacturing: industry location and change among low-tech, high-touch industries in Melbourne, Australia. Urban Geography, 1-23. http://dx.doi.org/10.1080/02723638.2020.1723329.

Gu, W., \& Yan, B. (2017). Productivity growth and international competitiveness. Review of Income and Wealth, 63, S113-S133. http:// dx.doi.org/10.1111/roiw.12254.

Hajkowicz, S. (2015). Global megatrends: seven patterns of change shaping our future. Melbourne: CSIRO Publishing. http://dx.doi. org/10.1071/9781486301416.

Hampson, 1. (2012). Industry policy under economic liberalism: Policy development in the prime minister's manufacturing task force. Economic and Labour Relations Review, 23(4), 39-56. http://dx.doi.org/10.1177/103530461202300404.

Hariharasudan, A., \& Kot, S. (2018). A scoping review on Digital English and Education 4.0 for Industry 4.0. Social Sciences, 7(11), 227. http://dx.doi.org/10.3390/socsci7110227.

Hasan, M., Trinh, N., Chan, F., Chan, H., \& Chung, S. (2011). Implementation of ERP of the Australian manufacturing companies. Industrial Management \& Data Systems, 111(1), 132-145. http://dx.doi.org/10.1108/02635571111099767.

Helfat, C., \& Peteraf, M. (2015). Managerial cognitive capabilities and the microfoundations of dynamic capabilities. Strategic Management Journal, 36(6), 997-1010. http://dx.doi.org/10.1002/smj.2247.

Helfat, C., \& Winter, S. (2011). Untangling dynamic and operational capabilities: Strategy for the (n)ever-changing world. Strategic Management Journal, 32(11), 1243-1250. http://dx.doi.org/10.1002/smj.955.

Hu, X., Chong, H., \& Wang, X. (2019). Sustainability perceptions of off-site manufacturing stakeholders in Australia. Journal of Cleaner Production, 227, 346-354. http://dx.doi.org/10.1016/j.jclepro.2019.03.258.

Jackson, P., Mavi, R., Suseno, Y., \& Standing, C. (2018). University-industry collaboration within the triple helix of innovation: The importance of mutuality. Science \& Public Policy, 45(4), 553-564. http://dx.doi.org/10.1093/scipol/scx083.

Jayaram, J., Oke, A., \& Prajogo, D. (2014). The antecedents and consequences of product and process innovation strategy implementation in Australian manufacturing firms. International Journal of Production Research, 52(15), 4424-4439. http://dx.doi.org/10.1080/0 0207543.2013.849363.

Joiner, T., Spencer, X., \& Salmon, S. (2009). The effectiveness of flexible manufacturing strategies. International Journal of Productivity and Performance Management, 58(2), 119-135. http://dx.doi.org/10.1108/17410400910928725.

Jones, J. (2005). The determinants of training in Australian manufacturing SMEs. Education + Training, 47(8-9), 605-615. http:// dx.doi.org/10.1108/00400910510633143.

Jones, J., \& Zubielqui, G. (2017). Doing well by doing good: A study of university-industry interactions, innovationess and firm performance in sustainability-oriented Australian SMEs. Technological Forecasting and Social Change, 123, 262-270. http://dx.doi. org/10.1016/j.techfore.2016.07.036.

Kalaitzi, D., Matopoulos, A., Fornasiero, R., Sardesai, S., Barros, A. C., Balech, S., \& Muerza, V. (2020). Megatrends and trends shaping supply chain innovation. In R. Fornasiero, S. Sardesai, A. C. Barros \& A. Matopoulos (Eds.), Next generation supply chains (pp. 3-34). Cham: Springer.

Kara, S., \& Kayis, B. (2007). Competing on capabilities-an analysis of supply chain flexibility in Australian manufacturing industry. International Journal of Risk Assessment and Management, X1), 79-99. http://dx.doi.org/10.1504/IJRAM.2007.011411.

Karim, M., Smith, A., \& Halgamuge, S. (2008). Empirical relationships between some manufacturing practices and performance. International Journal of Production Research, 46(13), 3583-3613. http://dx.doi.org/10.1080/00207540601164201.

Kayis, B., \& Kara, S. (2005). The supplier and customer contribution to manufacturing flexibility. Journal of Manufacturing Technology Management, 16(7), 733-752. http://dx.doi.org/10.1108/17410380510626169.

Kiridena, S., Hasan, M., \& Kerr, R. (2009). Exploring deeper structures in manufacturing strategy formation processes: a qualitative inquiry. International Journal of Operations \& Production Management, 29(4), 386-417. http://dx.doi.org/10.1108/01443570910945837.

Le, V., \& Valadkhani, A. (2014). Are exporting manufacturing SMEs more efficient than non-exporting ones? Evidence from Australia's business longitudinal database. Economic Analysis and Policy, 44(3), 310-317. http://dx.doi.org/10.1016/j.eap.2014.07.002.

Leahy, A., Palangkaraya, A., \& Yong, J. (2010). Geographical agglomeration in Australian manufacturing. Regional Studies, 44(3), 299314. http://dx.doi.org/10.1080/00343400902783248.

Levac, D., Colquhoun, H., \& O'Brien, K. (2010). Scoping studies: advancing the methodology. Implementation Science; IS, 5(1), 69. http://dx.doi.org/10.1186/1748-5908-5-69. PMid:20854677.

Li, W., Alvandi, S., Kara, S., Thiede, S., \& Herrmann, C. (2016). Sustainability Cockpit: an integrated tool for continuous assessment and improvement of sustainability in manufacturing. CIRP Annals - Manufacturing Technology, 65(1), 5-8. http://dx.doi.org/10.1016/j. cirp.2016.04.029.

Liu, L., \& McMurray, A. (2004). Frontline leaders: the entry point for leadership development in the manufacturing industry. Journal of European Industrial Training, 28(2-4), 339-352. http://dx.doi.org/10.1108/03090590410527708.

Lo, S., \& Power, D. (2010). An empirical investigation of the relationship between product nature and supply chain strategy. Supply Chain Management, 15(2), 139-153. http://dx.doi.org/10.1108/13598541011028741.

Lobo, S., Matawie, K., \& Samaranayake, P. (2012). Assessment and improvement of quality management capabilities for manufacturing industries in Australia. Total Quality Management \& Business Excellence, 23(1), 103-121. http://dx.doi.org/10.1080/14783363.2 011.639561.

Lobo, S., Matawie, K., Jayaraman, V., \& Samaranayake, P. (2009). An assessment of the quality management capabilities of the industries in the Western Sydney Region using a Quality Management Assessment Framework (QMAF). World Academy of Science, Engineering and Technology, 49, 1097-1106.

Lobo, S., Samaranayake, P., \& Laosirihongthong, T. (2018). Quality management capabilities of manufacturing industries in the Western Sydney region. International Journal of Quality \& Reliability Management, 35(6), 1232-1252. http://dx.doi.org/10.1108/ IJQRM-03-2017-0046. 
Logue, D., Argent, N., \& Warren, A. (2015). Wipeout? The Gold Coast and Tweed surfboard manufacturing cluster and local economic development. Local Economy, 30(1), 119-138. http://dx.doi.org/10.1177/0269094214562730.

Lopes, D., \& Barbosa, A. (2014). Management and organizational innovation in Brazil: evidence from technology innovation surveys. Production, 24(4), 872-886. http://dx.doi.org/10.1590/S0103-65132013005000076.

López-Gómez, C., Leal-Ayala, D., Palladino, M., \& O’Sullivan, E. (2017). Emerging trends in global advanced manufacturing: challenges, opportunities and policy responses. Vienna: United Nations Industrial Development Organization. Retrieved in 2020, March 26, from http://capacitydevelopment.unido.org/wp-content/uploads/2017/06/emerging_trends_global_manufacturing.pdf

López-Gómez, C., O’Sullivan, E., Gregory, M., Fleury, A., \& Gomes, L. (2013). Emerging trends in global manufacturing industries. Vienna: United Nations Industrial Development Organization.

Low, D., Chapman, R., \& Sloan, T. (2007). Inter-relationships between innovation and market orientation in SMEs. Management Research News, 30(12), 878-891. http://dx.doi.org/10.1108/01409170710833321.

Manufacturers' Monthly. (2019, April 8). Australia's top 100 manufacturing companies for 2019 revealed. Retrieved in 2020, July 23, from https://www.manmonthly.com.au/news/australias-top-100-manufacturing-companies-revealed/

Marks, A. (2009). The globalisation of the Australian passenger motor vehicle industry: lessons for other countries. Global Business and Economics Review, 11(2), 116-140. http://dx.doi.org/10.1504/GBER.2009.028980.

Matzler, K., Veider, V., \& Kathan, W. (2015). Adapting to the sharing economy. MIT Sloan Management Review, $56(2), 71$.

Mays, N., Roberts, E., \& Popay, J. (2001), Synthesizing research evidence. In N. Fulop, P. Allen, A. Clarke \& N. Black (Eds.), Studying the organisation and delivery of health services: research methods (pp. 188-219). London: Routledge.

Mazzarol, T. (2014, April 11). Does it matter if Australia no longer manufactures things? The Conversation. Retrieved in 2020, March 17, from https://theconversation.com/does-it-matter-if-australia-no-longer-manufactures-things-25541

McMillan, J., \& Western, J. (2000). Measurement of the socio-economic status of Australian higher education students. Higher Education, 39(2), 223-247. http://dx.doi.org/10.1023/A:1003943824357.

Mo, J. (2009). The role of lean in the application of information technology to manufacturing. Computers in Industry, 60(4), $266-276$. http://dx.doi.org/10.1016/j.compind.2009.01.002.

Moher, D., Liberati, A., Tetzlaff, J., \& Altman, D. (2009). Preferred reporting items for systematic reviews and meta-analyses: the PRISMA statement. Annals of Internal Medicine, 151(4), 264-269. http://dx.doi.org/10.7326/0003-4819-151-4-200908180-00135. PMid:19622511.

MoosaviRad, S., Kara, S., \& lbbotson, S. (2014). Impact of international outsourcing on the value adding of industries. International Journal of Logistics Management, 25(3), 463-486. http://dx.doi.org/10.1108/1JLM-05-2013-0061.

Munn, Z., Peters, M., Stern, C., Tufanaru, C., McArthur, A., \& Aromataris, E. (2018). Systematic review or scoping review? Guidance for authors when choosing between a systematic or scoping review approach. BMC Medical Research Methodology, 18(1), 143. http:// dx.doi.org/10.1186/s12874-018-0611-x. PMid:30453902.

Nascimento, D., Alencastro, V., Quelhas, O., Caiado, R., Garza-Reyes, J., Rocha-Lona, L., \& Tortorella, G. (2019). Exploring Industry 4.0 technologies to enable circular economy practices in a manufacturing context. Journal of Manufacturing Technology Management, 30(3), 607-627. http://dx.doi.org/10.1108/JMTM-03-2018-0071.

Nelson, S., Brunetto, Y., Farr-Wharton, R., \& Ramsay, S. (2007). Organisational effectiveness of Australian fast growing small to mediumsized enterprises (SMEs). Management Decision, 45(7), 1143-1162. http://dx.doi.org/10.1108/00251740710773952.

0'Connor, A., Du, K., \& Roos, G. (2015). The intellectual capital needs of a transitioning economy. Journal of Intellectual Capital, 16(3), 466-489. http://dx.doi.org/10.1108/JlC-08-2014-0097.

Okoli, C., \& Schabram, K. (2010). A guide to conducting a systematic literature review of information systems research. International Journal of Manufacturing Technology and Management, 10(26), 1-2.

Olive, M. (2008). Scale economies with regard to price adjustment costs and the speed of price adjustment in Australian manufacturing. International Review of Applied Economics, 22(1), 63-75. http://dx.doi.org/10.1080/02692170701745895.

Oliver, D., \& Walpole, K. (2017). How are links between a National Qualifications Framework, job roles and pay mediated by industrial relations institutions in manufacturing? Journal of Vocational Education and Training, 69(4), 576-595. http://dx.doi.org/10.1080 /13636820.2017.1326162.

Organisation for Economic Cooperation and Development - OECD. (2020). Revenue statistics in Asian and Pacific Economies 2020. Retrieved in 2020, July 14, from https://www.oecd-ilibrary.org/australia

Pagliaro, M. (2019). An industry in transition: The chemical industry and the megatrends driving its forthcoming transformation. Angewandte Chemie International Edition, 58(33), 11154-11159. http://dx.doi.org/10.1002/anie.201905032. PMid:31112627.

Pagliosa, M., Tortorella, G., \& Ferreira, J. (2019). Industry 4.0 and Lean Manufacturing: a systematic literature review and future research directions. Journal of Manufacturing Technology Management. In press. http://dx.doi.org/10.1108/JMTM-12-2018-0446.

Pancholi, S., Yigitcanlar, T., \& Guaralda, M. (2019). Place making for innovation and knowledge-intensive activities: The Australian experience. Technological Forecasting and Social Change, 146, 616-625. http://dx.doi.org/10.1016/j.techfore.2017.09.014.

Penesis, 1., Barnes, R., Kilpatrick, S., Symes, M., \& León de la Barra, B. (2017). Reskilling the manufacturing workforce and developing capabilities for the future. Australasian Journal of Engineering Education, 22(1), 14-22. http://dx.doi.org/10.1080/22054952.201 7.1338228.

Perera, S., Soosay, C., \& Sandhu, S. (2019). Investigating the strategies for supply chain agility and competitiveness. AJBA, 12(1), 279312. http://dx.doi.org/10.22452/ajba.vol12no1.10.

Peters, V., Meijboom, B., \& De Vries, E. (2018). Interfaces in service modularity: a scoping review. International Journal of Production Research, 56(20), 6591-6606. http://dx.doi.org/10.1080/00207543.2018.1461270.

Peterson, J., Pearce, P., Ferguson, L., \& Langford, C. (2017). Understanding scoping reviews: definition, purpose, and process. Journal of the American Association of Nurse Practitioners, 29(1), 12-16. http://dx.doi.org/10.1002/2327-6924.12380. PMid:27245885. 
Pham, M., Raji $\square$, A., Greig, J., Sargeant, J., Papadopoulos, A., \& McEwen, S. (2014). A scoping review of scoping reviews: advancing the approach and enhancing the consistency. Research Synthesis Methods, 5(4), 371-385. http://dx.doi.org/10.1002/jrsm.1123. PMid:26052958.

Popa, S., Soto-Acosta, P., \& Perez-Gonzalez, D. (2018). An investigation of the effect of electronic business on financial performance of Spanish manufacturing SMEs. Technological Forecasting and Social Change, 136, 355-362. http://dx.doi.org/10.1016/j. techfore.2016.08.012.

Prajogo, D. (2006). Progress of quality management practices in Australian manufacturing firms. The TQM Magazine, 18(5), 501-513. http://dx.doi.org/10.1108/09544780610685476.

Prajogo, D. (2007). The relationship between competitive strategies and product quality. Industrial Management \& Data Systems, 107(1), 69-83. http://dx.doi.org/10.1108/02635570710719061.

Prajogo, D., Chowdhury, M., Yeung, A., \& Cheng, T. (2012). The relationship between supplier management and firm's operational performance: a multi-dimensional perspective. International Journal of Production Economics, 136(1), 123-130. http://dx.doi. org/10.1016/j.jpe.2011.09.022.

Qureshi, A., \& Evans, N. (2015). Deterrents to knowledge-sharing in the pharmaceutical industry: a case study. Journal of Knowledge Management, 19(2), 296-314. http://dx.doi.org/10.1108/JKM-09-2014-0391.

Reid, M. (2001). Benchmarking NPD Success Factors in the Australian Food Processing Industry. Journal of Food Products Marketing, 7(4), 19-35. http://dx.doi.org/10.1300/J038v07n04_03.

Ridley, D. (2012). The literature review: a step-by-step guide for students. London: Sage.

Rosen, P., \& Wischniewski, S. (2019). Scoping review on job control and occupational health in the manufacturing context. International Journal of Advanced Manufacturing Technology, 102(5-8), 2285-2296. http://dx.doi.org/10.1007/s00170-018-03271-z.

Rossini, M., Costa, F., Tortorella, G., \& Portioli-Staudacher, A. (2019). The interrelation between lndustry 4.0 and lean production: an empirical study on European manufacturers. International Journal of Advanced Manufacturing Technology, 102(9-12), 3963-3976. http://dx.doi.org/10.1007/s00170-019-03441-7.

Salvato, C., \& Vassolo, R. (2018). The sources of dynamism in dynamic capabilities. Strategic Management Journal, 39(6), $1728-1752$. http://dx.doi.org/10.1002/smj.2703.

Samson, D., \& Gloet, M. (2018). Integrating performance and risk aspects of supply chain design processes. Production Planning and Control, 29(15), 1238-1257. http://dx.doi.org/10.1080/09537287.2018.1520314.

Schilke, 0. (2014). The contingent value of dynamic capabilities for competitive advantage: The nonlinear moderating effect of environmental dynamism. Strategic Management Journal, 35(2), 179-203. http://dx.doi.org/10.1002/smj.2099.

Schliephake, K., Stevens, G., \& Clay, S. (2009). Making resources work more efficiently-the importance of supply chain partnerships. Journal of Cleaner Production, 17(14), 1257-1263. http://dx.doi.org/10.1016/j.jclepro.2009.03.020.

Seo $\square$ Zindy, R., \& Heeks, R. (2017). Researching the emergence of 3D printing, makerspaces, hackerspaces and fablabs in the global south: a scoping review and research agenda on digital innovation and fabrication networks. The Electronic Journal on Information Systems in Developing Countries, 80(1), 1-24. http://dx.doi.org/10.1002/j.1681-4835.2017.tb00589.x.

Sharma, B. (2003). R\&D strategy and Australian manufacturing industry: an empirical investigation of emphasis and effectivness. Technovation, 23(12), 929-937. http://dx.doi.org/10.1016/S0166-4972(02)00035-4.

Sharma, B. (2004). Marketing strategy, contextual factors and performance. Marketing Intelligence \& Planning, 22(2), 128-143. http:// dx.doi.org/10.1108/02634500410525823.

Sheather, G. (2002). Transforming Australian manufacturing enterprises for global competitiveness. International Journal of Technology Management, 24(5-6), 514-541. http://dx.doi.org/10.1504/1JTM.2002.003068.

Siddaway, A., Wood, A., \& Hedges, L. (2019). How to do a systematic review: a best practice guide for conducting and reporting narrative reviews, meta-analyses, and meta-syntheses. Annual Review of Psychology, 70(1), 747-770. http://dx.doi.org/10.1146/ annurev-psych-010418-102803. PMid:30089228.

Silva, D., Silva, E., \& Ometto, A. (2016). Green manufacturing: uma análise da produção científica e de tendências para o futuro. Production, 26(3), 642-655. http://dx.doi.org/10.1590/0103-6513.032513.

Silveira, G., Fogliatto, F., \& Fendyur, A. (2016). Demographics of mass customization: a global study of manufacturing plants. Production, 26(1), 1-11. http://dx.doi.org/10.1590/0103-6513.163113.

Singh, P., \& Power, D. (2014). Innovative knowledge sharing, supply chain integration and firm performance of Australian manufacturing firms. International Journal of Production Research, 52(21), 6416-6433. http://dx.doi.org/10.1080/00207543.2013.859760.

Singh, S. (2012). New mega trends: implications for our future lives. London: Springer. http://dx.doi.org/10.1057/9781137008091.

Smith, E., Smith, A., \& Smith, C. (2010). Old dogs, new tricks: training mature-aged manufacturing workers. Journal of Workplace Learning, 22(5), 277-291. http://dx.doi.org/10.1108/13665621011053190.

Smith, E., Smith, A., Hampson, 1., \& Junor, A. (2015). How closely do Australian Training Package qualifications reflect the skills in occupations? An empirical investigation of seven qualifications. International Journal of Training Research, 13(1), 49-63. http:// dx.doi.org/10.1080/14480220.2015.1051351.

Smith, M. (2007). "Real" managerial differences between family and non-family firms. International Journal of Entrepreneurial Behaviour \& Research, 13(5), 278-295. http://dx.doi.org/10.1108/13552550710780876.

Sohal, A. (2000). Computer integrated manufacturing in the Australian pharmaceutical industry. Integrated Manufacturing Systems, 11(7), 444-453. http://dx.doi.org/10.1108/09576060010349749.

Sohal, A. (2001). From privatisation to commercialisation: a case study from the Australian aerospace industry. International Journal of Technology Management, 21(5-6), 513-522. http://dx.doi.org/10.1504/IJTM.2001.002930.

Sohal, A., \& Terziovski, M. (2000). TQM in Australian manufacturing: factors critical to success. International Journal of Quality \& Reliability Management, 17(2), 158-168. http://dx.doi.org/10.1108/02656710010304564. 
Sohal, A., Moss, S., \& Ng, L. (2001). Comparing IT success in manufacturing and service industries. International Journal of Operations \& Production Management, $21(1-2), 30-45$. http://dx.doi.org/10.1108/01443570110358440.

Sohal, A., Power, D., \& Terziovski, M. (2002). Supply chain management in Australian manufacturing: two case studies. Computers \& Industrial Engineering, 43(1-2), 97-109. http://dx.doi.org/10.1016/S0360-8352(02)00069-4.

Soosay, C., Nunes, B., Bennett, D., Sohal, A., Jabar, J., \& Winroth, M. (2016). Strategies for sustaining manufacturing competitiveness: comparative case studies in Australia and Sweden. Journal of Manufacturing Technology Management, 27(1), 6-37. http://dx.doi. org/10.1108/JMTM-04-2014-0043.

Stank, T., Autry, C., Daugherty, P., \& Closs, D. (2015). Reimagining the 10 megatrends that will revolutionize supply chain logistics. Transportation Journal, 54(1), 7-32. http://dx.doi.org/10.5325/transportationj.54.1.0007.

Stewart, J. (2016). Path dependence, policy learning and Australian manufacturing since the 1970s. Australian Journal of Political Science, 51(4), 652-666. http://dx.doi.org/10.1080/10361146.2016.1239568.

Teng, C., O’Neill, P., \& Foley, L. (2014). Innovative manufacturing in Australia's emerging regenerative medicine industry: centralised factories to decentralised facilities. International Journal of Production Research, 52(21), 6538-6556. http://dx.doi.org/10.1080/0 0207543.2014.962115.

Teo, S., Le Clerc, M., \& Galang, M. (2011). Human capital enhancing HRM systems and frontline employees in Australian manufacturing SMEs. International Journal of Human Resource Management, 22(12), 2522-2538. http://dx.doi.org/10.1080/09585192.2011.588034.

Tortorella, G., \& Fogliatto, F. (2008). Planejamento sistemático de layout com apoio de análise de decisão multicritério. Production, 18(3), 609-624. http://dx.doi.org/10.1590/S0103-65132008000300015.

Tortorella, G., Fogliatto, F., Mac Cawley Vergara, A., Vassolo, R., \& Sawhney, R. (2019). Healthcare 4.0: trends, challenges and research directions. Production Planning and Control

Truett, L., \& Truett, D. (2017). Cost relationships and globalization in the Australian clothing industry. Applied Economics, 49(46), 4638-4656. http://dx.doi.org/10.1080/00036846.2017.1287864.

Truett, L., \& Truett, D. (2018). A requiem for the Australian motor vehicle industry. Applied Economics, 50(40), 4343-4359. http:// dx.doi.org/10.1080/00036846.2018.1444265.

Tung, A., Baird, K., \& Schoch, H. (2011). Factors influencing the effectiveness of performance measurement systems. International Journal of Operations \& Production Management, 31(12), 1287-1310. http://dx.doi.org/10.1108/01443571111187457.

Turnbull, C., Sun, S., \& Anwar, S. (2016). Trade liberalisation, inward FDI and productivity within Australia's manufacturing sector. Economic Analysis and Policy, 50, 41-51. http://dx.doi.org/10.1016/j.eap.2016.02.004.

United Nations Conference on Trade and Development - UNCTAD. (2017). The role of the services economy and trade in structural transformation and inclusive development. Geneva: United Nations.

Van der Eng, P. (2017). European integration and australian manufacturing industry: the case of Philips electronics, 1960s-1970s. Australian Economic History Review, 57(2), 217-238. http://dx.doi.org/10.1111/aehr.12103.

Watts, D., Yapa, P., \& Dellaportas, S. (2014). The case of a newly implemented modern management accounting system in a multinational manufacturing company. Australasian Accounting, Business and Finance Journal, 8(2), 121-137. http://dx.doi.org/10.14453/aabfj.v8i2.9.

Weller, S., \& O'Neill, P. (2014). De-industrialisation, financialisation and Australia's macro-economic trap. Cambridge Journal of Regions, Economy and Society, 7(3), 509-526. http://dx.doi.org/10.1093/cjres/rsu020.

Westkämper, E. (2014). Global "Megatrend's" grand societal challenges. In E. Westkämper (Ed.), Towards the re-industrialization of Europe (pp. 17-22). Berlin: Springer. http://dx.doi.org/10.1007/978-3-642-38502-5_4.

World Economic Forum. (2019). Fourth industrial revolution: beacons of technology and innovation in manufacturing. Geneva. Retrieved in 2020, March 26, from http://www3.weforum.org/docs/WEF_4IR_Beacons_of_Technology_and_lnnovation_in_Manufacturing_ report_2019.pdf

Wright, C., Clibborn, S., \& Lansbury, R. (2011). Becoming an endangered species? The future viability of Australian automotive manufacturing. International Journal of Automotive Technology and Management, 11(2), 172-188. http://dx.doi.org/10.1504/1JATM.2011.039543.

Yigitcanlar, T., Sabatini-Marques, J., da-Costa, E. M., Kamruzzaman, M., \& loppolo, G. (2019). Stimulating technological innovation through incentives: Perceptions of Australian and Brazilian firms. Technological Forecasting and Social Change, 146, 403-412. http://dx.doi.org/10.1016/j.techfore.2017.05.039.. 